\title{
Genetic polymorphisms and asthma: findings from a case-control study in the Madeira island population
}

Anabela Gonçalves Berenguer ${ }^{1,5^{*}}$, Ana Teresa Fernandes', Susana Oliveira ${ }^{2}$, Mariana Rodrigues ${ }^{3}$, Pedro Ornelas ${ }^{2}$, Diogo Romeira ${ }^{2}$, Tânia Serrão ${ }^{2}$, Alexandra Rosa ${ }^{1,4 \dagger}$ and Rita Câmara ${ }^{2 \dagger}$

\begin{abstract}
Background: Asthma is a complex disease influenced by multiple genetic and environmental factors. While Madeira has the highest prevalence of asthma in Portugal (14.6\%), the effect of both genetic and environmental factors in this population has never been assessed. We categorized 98 asthma patients according to the Global Initiative for Asthma (GINA) guidelines, established their sensitization profile, and measured their forced expiratory volume in 1 second $\left(F E V_{1}\right)$ and forced vital capacity (FVC) indexes. Selected single nucleotide polymorphisms (SNPs) were analysed as potential markers for asthma susceptibility and severity in the interleukin 4 (IL4), interleukin 13 (IL13), beta-2-adrenergic receptor (ADRB2), a disintegrin and metalloprotease 33 (ADAM33), gasdermin-like (GSDML) and the signal transducer and activator of transcription 6 (STAT6) genes comparatively to a population reference set.

Results: Although mites are the major source of allergic sensitization, no significant difference was found amongst asthma severity categories. IL4-590*CT/TT and IL4-RP2*253183/183183 were found to predict the risk (2-fold) and severity (3 to 4-fold) of asthma and were associated with a lower $\mathrm{FEV}_{1}$ index. ADRB2-c.16*AG is a risk factor (3.5-fold), while genotype GSDML-236*TT was protective (4-fold) for moderate-severe asthma. ADAM33-V4*C was associated to asthma and mild asthma by the transmission disequilibrium test (TDT). Finally, ADAM33-V4*CC and STAT6-21*TT were associated with higher sensitization (mean wheal size $\geq 10 \mathrm{~mm}$ ) to house dust (1.4-fold) and storage mite (7.8-fold).
\end{abstract}

Conclusion: In Madeira, IL4-590C/T, IL4-RP2 253/183, GSDML-236C/T and ADAM33-V4C/G SNPs are important risk factors for asthma susceptibility and severity, with implications for asthma healthcare management.

Keywords: Asthma, Madeira, SNPs, Susceptibility, Severity

\section{Background}

Asthma is a chronic airway inflammation, characterized by variable airway obstruction and reduced lung function, and leading to wheezing and shortness of breath [1]. It is described as a complex disease arising from the contribution of multiple genetic and environmental factors [2,3], affecting more than 300 million people worldwide, with increased prevalence in developed societies [4].

\footnotetext{
* Correspondence: anabela.berenguer@oulu.fi

${ }^{\dagger}$ Equal contributors

${ }^{1}$ Human Genetics Laboratory, University of Madeira, 9000-390 Funchal,

Portugal

${ }^{5}$ Department of Computer Science and Engineering, University of Oulu, PL 4500, 90014 Oulu, Finland

Full list of author information is available at the end of the article
}

In Portugal, $7.83 \%$ of the population is affected by clinical asthma and $8.72 \%$ by wheezing symptoms [5]. Within Portugal, the island of Madeira has a high prevalence of the disease, as active asthma (presence of symptoms during the last 12 months) affects $14.6 \%$, and atopy (positive reaction to skin prick tests (SPT) to common aeroallergens and the presence of specific IgE) affects $54 \%$ of the population [6].

Given the high prevalence of asthma in the Madeira population [6], determining the population's genetic background is an essential first step towards understanding the mechanisms of the disease. In previous work [7] we showed that both IL4-590 and IL4-RP2 are useful genetic markers to detect asthma predisposition in the Madeira population. Investigating a larger number of 
genes is important because many genes with small effects, rather than just a few with strong effects, contribute to the disease risk [8]. A useful clustering of asthma susceptibility genes has been proposed [9]: i) triggers of the immune response (such as CD14, IL10, STAT3, MHC class II molecules); ii) regulators of the $\mathrm{T}$ helper 2 (Th2) differentiation (IL12B, IL4, IL13, STAT6, IL4RA); iii) associated with epithelial biology (CCL5, FLG, SPINK5, GSDML) and iv) linked to lung function, airway remodeling and asthma severity (ADRB2, ADAM33, DPP10, PHF11).

Here we extend our analysis in four important ways, to consider i) 6 additional polymorphisms, namely IL13-c.144 G/A, ADRB2-c.16 A/G, ADAM33-V4 C/G, ADAM33-S1 c.710 G/A, GSDML-236 C/T and STAT6-21 $C / T$ (guided by a literature review summarized in Table 1 ), ii) the asthma persistence and severity classes according to GINA guidelines, iii) the most common allergens in the island and iv) the $\mathrm{FEV}_{1} / \mathrm{FVC}$ lung function indexes. Therefore, this work contributes to the analysis of the association of the above polymorphisms to asthma susceptibility and severity, $\mathrm{FEV}_{1} / \mathrm{FVC}$ indexes and sensitization profiles, in the Madeira population.

\section{Results}

Demographic and clinical characterization of the asthmatics The demographic and clinical characterization of the asthmatic population analysed in this study are shown in Table 2. The patients' mean age was $13.6 \pm 4.3$ years old, with $59.2 \%$ males. None of the asthma persistence or severity phenotypes was found sub-structured by the male-tofemale ratio. The $\mathrm{FEV}_{1}$ and FVC indexes were significantly different between mild persistent and moderate-severe persistent asthma (Mean $\mathrm{FEV}_{1} \mathrm{t}=2.732$, $\mathrm{p}$-value $=0.008$; FVC Mann-Whitney U = 456.0, p-value $=0.025$ ).

Although persistent asthmatics were found more frequently sensitized to both cat and dog allergen than intermittent asthmatics (Additional file 1) no significant differences were observed for SPT positivity or degree of sensitization to the most common allergens in the island, namely dust and storage mites mix fungi, indoor fungi, cat or dog.

\section{SNP association to asthma risk and severity}

The genotypic and allelic frequencies of each SNP among asthma subgroups and population reference set are described in Table 3 and Additional file 2, respectively. The genotypic distribution of SNPs in controls reflects previously published data on other European and Mediterranean populations $[45,46]$. All SNP polymorphisms were found to be in HWE, except for STAT6-21 locus in mild persistent asthma ( $p$-value $=0.038)$. Nevertheless, this SNP was considered in the analysis under a more stringent $\mathrm{p}$-value cut-off of 0.01, since a slight deviation from HWE is allowed for SNPs linked to disease status [47].

Table 3 shows significant effects for the genotypes IL4-590*CT/TT, IL4-RP2*183253/183183, ADRB2-c.16*AG/ $A A$, and GSDML-236*TT. Specifically, the IL4-590*CT/TT genotypes were significantly more frequent in asthma patients $\left(35.8 \%\right.$ vs. $20.0 \%, \chi^{2}$ p-value $=0.009$; OR 2.222, 95\% CI 1.191-4.146), persistent asthma (37.8\% vs. 20.0\%; $\mathrm{X}^{2}$ p-value $=0.006$; OR 2.433, 95\% CI 1.264-4.717), and moderate-severe asthma $v s$. the reference set $(20 \% v s$. 50.0\%; $\chi^{2}$ p-value $=0.002$; OR 4.000, 95\% CI 1.701-9.434). Genotypes IL4-RP2*183253/183183 were significantly more frequent in asthma patients $\left(30.7 \%\right.$ vs. $18.2 \%$; $\chi^{2}$ p-value $=0.027$; OR $1.984,95 \%$ CI 1.040-3.788), in persistent asthma (33.8\% vs. $18.2 \%$; $\mathrm{X}^{2} \mathrm{p}$-value $=0.013$; OR 2.296, 95\% CI 1.159-4.547), and in the moderate-severe asthma vs. the reference set $\left(46.7 \%\right.$ vs. $18.2 \% ; \chi^{2}$ p-value $=0.002$; OR $3.938,95 \%$ CI 1.657-9.357). ADRB2-c.16*AG was significantly more frequent in moderate-severe asthma $v s$. mild asthma (66.7\% vs. $36.4 \%$, p-value $=0.010$, OR 3.500, 95\% CI 1.318-9.293) while GSDML-236*TT displays a significant opposite trend $(20.0 \%$ and $50.0 \%$, respectively in moderate-severe and mild asthma; $\chi^{2} \mathrm{p}$-value $=0.008,0 \mathrm{R}$ 0.250 95\% CI 0.086-0.730).

The results described above are corroborated by the allelic counts (Additional file 2) of IL4-590*T, which are significantly higher in asthma patients $\left(19.4 \%\right.$; $\chi^{2}$ p-value $=0.010$, OR 2.060, 95\% CI 1.178-3.601), in persistent asthma $\left(20.3 \% \chi^{2}\right.$ p-value $=0.009$, OR 2.178 95\% CI 1.208-3.925), and in moderate-severe (28.3\%, $X^{2}$ p-value $=4.514 * 10^{-4}$, OR $3.38695 \%$ CI 1.668-6.877)

Table 1 Selected studies previously reporting association of the studied SNPs and asthma

\begin{tabular}{|c|c|c|c|c|c|}
\hline Gene & Polymorphism & dbSNP rs ref (NCBI) & Chromosome location & Alleles (ancestral:derived) & References \\
\hline 1213 & c.144GIn/Arg & rs 20541 & $5 q 31$ exon 4 & $G>A$ & {$[10-16]$} \\
\hline IL4 & 590 & rs2243250 & $5 q 31$ promoter & $C>T$ & {$[17-23]$} \\
\hline IL4 & $R P 2$ & - & $5 q 31$ intron 2 & $253>183$ (del) & [24] \\
\hline ADRB2 & c.16Arg/Gly & rs1042713 & $5 q 31$ exon & $A>G$ & {$[25,26]$} \\
\hline ADAM33 & V4 & rs2787094 & 20p13 3'UTR & $C>G$ & {$[27-30]$} \\
\hline ADAM33 & S1 c.710Val/lle & rs3918396 & 20p13 exon 19 & $G>A$ & {$[27]$} \\
\hline GSDML & 236 & rs7216389 & 17q21 intron 1 & $C>T$ & {$[31-39]$} \\
\hline STAT6 & 21 & rs324011 & 12q13-24 intron 2 & $C>T$ & {$[19,40-44]$} \\
\hline
\end{tabular}


Table 2 Clinical characterization of the asthmatics study population

\begin{tabular}{|c|c|c|c|c|c|c|}
\hline & \multicolumn{6}{|c|}{ Study sample set } \\
\hline & Overall asthma & Intermittent asthma & Persistent asthma & Mild & Moderate-severe & $\mathrm{p}$-value \\
\hline Sample size $(n, \%)$ & $98(100.0)$ & $24(24.5)$ & $74(75.5)$ & $44(59.9)$ & $30(40.5)$ & \\
\hline Male/Female (\%) & $59.2 / 40.8$ & $62.5 / 37.5$ & $58.1 / 41.9$ & $54.5 / 45.5$ & $63.3 / 36.7$ & \\
\hline Mean age (years +- s.d.) & $13.6+-4.3$ & $14.1+-3.5$ & $13.4+-4.5$ & $14.3+-4.6$ & $12.0+-4.1$ & \\
\hline Mean FEV 1 (\%) & $96.9+-14.7$ & $98.5+-16.3$ & $96.4+-14.2$ & $99.9+-10.7$ & $91.2+-17.1$ & 0.008 \\
\hline Mean FVC (\%) & $95.0+-12.8$ & $97.4+-12.1$ & $94.3+-13.0$ & $97.3+-9.9$ & $89.8+-15.6$ & 0.025 \\
\hline
\end{tabular}

Asthma classification according to GINA [75].

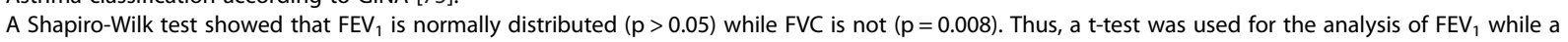
Mann-Whitney test was used for FVC. Statistically significant p-values were found for comparisons between mild persistent and moderate-severe persistent asthma, denoted in bold.

vs. the reference set (10.5\%). Similarly, the allelic counts of IL4-RP2*183 were significantly higher in moderate-severe vs. the reference set $\left(26.7 \%\right.$ vs. $10.5 \% ; X^{2}$ p-value $=0.001$, OR 3.115 95\% CI 1.521-6.379).

\section{SNP association to $\mathrm{FEV}_{1}$ and FVC}

Table 4 shows the association analysis of SNP genotypes with the $\mathrm{FEV}_{1}$ and FVC indexes. Significant differences were found for mean $\mathrm{FEV}_{1}$ distribution among $I L 4-590^{*} \mathrm{C} / \mathrm{T}$ genotypes $(\mathrm{F}=3.982$, $\mathrm{p}$-value $=0.024)$, with $I L 4-590^{\circ} C T / T T$ patients exhibiting a significantly lower $\mathrm{FEV}_{1}$ values when compared to IL4-590*CC homozygotes patients $(\mathrm{t}=2.797$, $\mathrm{p}$-value $=0.006$ ). Similarly, a significantly lower $\mathrm{FEV}_{1}$ index was found amongst patients with IL4-RP2*183253/183183 when compared to IL4-RP2*253253 homozygotes $(\mathrm{t}=2.974$, p-value $=0.004$ ).

\section{SNP association to SPT}

Despite not associated to SPT positivity, some of the studied SNPs relate to the sensitization degree (Table 5). ADAM33-V4*CC relates to house dust mite (Dermatophagoides pteronyssinus $\chi^{2} \mathrm{p}$-value $=0.016$, OR 1.325, 95\% CI 1.070-1.641 and Blomia tropicalis $X^{2}$ $\mathrm{p}$-value $=0.047$, OR 1.355 , 95\% CI 1.131-1.622). STAT6$21 * T T$ is associated to the degree of sensitization for storage mite $\left(\chi^{2}\right.$-value $=0.003$, OR 7.778, 95\% CI 1.682- 35.962).

\section{SNP haplotypes and epistasis association to asthma risk}

Table 6 shows the haplotype frequencies for SNPs at the $5 \mathrm{q} 31$ and $20 \mathrm{p} 13$ chromosomal regions. At the 5q31, we highlight IL4-590/IL4-RP2* T183 frequency, which is significantly lower in the reference set $(8.8 \%)$ than overall asthma $(16.8 \%, \mathrm{p}$-value $=0.019)$, persistent asthma $(18.2 \%$, $\mathrm{p}$-value $=0.011)$, and moderate-severe asthma $\left(26.7 \%\right.$, $\mathrm{p}$-value $\left.=3 \times 10^{-4}\right)$. In addition, this same haplotype was more common in moderate-severe $v s$. mild asthma $(26.7 \%$ vs. $12.5 \%$, p-value $=0.029)$. In fact, every haplotype found to associate with the risk of asthma includes either IL4-590 C/T or IL4-RP2183/253 or both. Compared to the reference set, the most significant combinations are i) overall asthma IL13c.144/IL4-590*GT (p-value $=0.018)$; ii) persistent asthma IL13c.144/IL4$590 * G T(\mathrm{p}$-value $=0.010)$ and iii $)$ moderate-severe asthma IL4-590/IL4-RP2*T183 (p-value $\left.=3 \times 10^{-4}\right)$. IL13c.144/IL4$R P 2 * A 183$ is also more frequently found in moderatesevere asthma than in mild asthma ( $\mathrm{p}$-value $=0.017$ ).

Epistatic interactions between pairs of SNPs between all asthma subgroups were tested, revealing significant epistasis for loci IL4-590 and STAT6-21 in moderate-to-severe compared to intermittent asthma ( $\mathrm{p}$-value $=0.044)$ and IL13-c.144 and ADAM33-V4 between persistent asthma and the Madeira reference set $(\mathrm{p}$-value $=0.035)$.

\section{TDT association analysis}

The TDT analysis in Table 7 suggests that the ADAM33$V 4 * C$ allele is significantly over transmitted to offsprings in overall asthma (ratio 27/15 of transmitted/non-transmitted; McNemar $\chi^{2}$ 3.429, p-value $=0.044$, OR $1.800,95 \%$ CI 0.956-3.384), in persistent asthma (ratio 22/9 of transmitted/ non-transmitted; McNemar $\chi^{2}$ 5.452, $\mathrm{p}$-value $=0.015$ OR 2.444, 95\% CI 1.126-5.309), and in mild asthma (ratio 16/4 of transmitted/non-transmitted; McNemar $\chi^{2} 7.200$ p-value $=0.006$ OR 4.000, 95\% CI 1.337-11.965). IL4-590*T and IL4-RP2*183 alleles were found to be significantly over transmitted only amongst moderate-severe offspring asthma (ratio 15/6 of transmitted/non-transmitted; McNemar $\chi^{2}$ 3.857, $\mathrm{p}$-value $=0.039$ OR $2.500,95 \% \mathrm{CI}$ 0.970-6.443 and ratio 14/4 of transmitted/non-transmitted; McNemar $\chi^{2} 5.556$, p-value $=0.015$ OR 3.500, 95\% CI 1.152-10.663, respectively).

\section{Discussion}

In the asthmatic patients studied, $24.5 \%$ are classified as intermittent asthmatics while the remaining are persistent asthmatics (of which $40.5 \%$ show moderate-severe forms of the disease). The significant differences we observed for $\mathrm{FEV}_{1}$ and $\mathrm{FVC}$ indexes denote these as reliable indicators for disease severity, as previous stated by a number of studies [48-50].

SNP IL4-590 C/T has been repeatedly associated to asthma in several population backgrounds [17-22] and the results of this study in the Madeira island population 
Table 3 SNP genotypic frequencies for the Madeira reference set and asthmatics study population

\begin{tabular}{|c|c|c|c|c|c|c|}
\hline \multirow[t]{2}{*}{ SNP genotypes } & \multicolumn{6}{|c|}{ Study sample set } \\
\hline & Madeira reference set & Overall asthma & Intermittent asthma & Persistent asthma & Mild & Moderate-severe \\
\hline & $105^{\mathrm{a}}$ & 98 & 24 & 74 & 44 & 30 \\
\hline \multicolumn{7}{|l|}{ IL4-590 C/T } \\
\hline $\mathrm{CC}$ & 0.800 & 0.643 & 0.708 & 0.622 & 0.705 & 0.500 \\
\hline $\mathrm{CT}$ & 0.191 & 0.327 & 0.250 & 0.351 & 0.295 & 0.433 \\
\hline$\pi$ & 0.009 & 0.031 & 0.042 & 0.027 & 0 & 0.067 \\
\hline p-value & & 0.009 & & 0.006 & & 0.002 \\
\hline OR $(95 \% \mathrm{Cl})$ & & $2.222(1.191-4.146)$ & & $2.433(1.264-4.717)$ & & $4.000(1.701-9.434)$ \\
\hline \multicolumn{7}{|l|}{ IL4-RP2 253/183 } \\
\hline 253253 & 0.818 & 0.694 & 0.792 & 0.662 & 0.750 & 0.533 \\
\hline 183253 & 0.155 & 0.276 & 0.167 & 0.311 & 0.250 & 0.400 \\
\hline 183183 & 0.027 & 0.031 & 0.042 & 0.027 & 0 & 0.067 \\
\hline p-value & & 0.027 & & 0.013 & & 0.002 \\
\hline OR $(95 \% \mathrm{Cl})$ & & $1.984(1.040-3.788)$ & & $2.296(1.159-4.547)$ & & $3.938(1.657-9.357)$ \\
\hline \multicolumn{7}{|l|}{ IL13-C.144 G/A } \\
\hline GG & 0.676 & 0.704 & 0.625 & 0.730 & 0.773 & 0.667 \\
\hline GA & 0.305 & 0.267 & 0.333 & 0.257 & 0.205 & 0.333 \\
\hline $\mathrm{AA}$ & 0.019 & 0.020 & 0.042 & 0.014 & 0.023 & 0 \\
\hline \multicolumn{7}{|l|}{ ADRB2-c.16 A/G } \\
\hline AA & 0.181 & 0.194 & 0.250 & 0.176 & 0.250 & 0.067 \\
\hline$A G$ & 0.457 & 0.480 & 0.458 & 0.486 & 0.364 & 0.667 \\
\hline GG & 0.362 & 0.327 & 0.292 & 0.338 & 0.386 & 0.267 \\
\hline p-value & & & & & & $0.010^{*}$ \\
\hline OR $(95 \% \mathrm{Cl})$ & & & & & & $3.500(1.318-9.293)$ \\
\hline \multicolumn{7}{|l|}{ ADAM33-V4 C/G } \\
\hline GG & 0.029 & 0.010 & 0 & 0.014 & 0.023 & 0 \\
\hline$C G$ & 0.209 & 0.235 & 0.292 & 0.216 & 0.182 & 0.267 \\
\hline $\mathrm{CC}$ & 0.762 & 0.755 & 0.708 & 0.770 & 0.795 & 0.733 \\
\hline \multicolumn{7}{|l|}{ ADAM33-S1c.710 } \\
\hline G/A GG & 0.905 & 0.929 & 0.917 & 0.932 & 0.932 & 0.933 \\
\hline GA & 0.095 & 0.071 & 0.083 & 0.068 & 0.068 & 0.067 \\
\hline AA & 0 & 0 & 0 & 0 & 0 & 0 \\
\hline \multicolumn{7}{|l|}{ GSDML-236 C/T } \\
\hline CC & 0.171 & 0.163 & 0.167 & 0.162 & 0.136 & 0.200 \\
\hline$C T$ & 0.467 & 0.469 & 0.500 & 0.459 & 0.364 & 0.600 \\
\hline$\pi$ & 0.362 & 0.367 & 0.333 & 0.378 & 0.500 & 0.200 \\
\hline p-value & & & & & & $0.008^{* *}$ \\
\hline OR $(95 \% \mathrm{Cl})$ & & & & & & $0.250(0.086-0.730)$ \\
\hline
\end{tabular}


Table 3 SNP genotypic frequencies for the Madeira reference set and asthmatics study population (Continued)

\begin{tabular}{cccccccc}
\hline$C C$ & 0.428 & 0.449 & 0.417 & 0.459 & 0.523 & 0.367 \\
$C T$ & 0.486 & 0.418 & 0.458 & 0.405 & 0.295 & 0.567 \\
$\pi$ & 0.086 & 0.133 & 0.125 & 0.135 & 0.182 & 0.067 \\
\hline
\end{tabular}

a) Except for IL4-590 and IL4-RP2 ( $\mathrm{n}=110)$;

b) Polymorphism not in HWE for mild asthma (p-value $=0.038$ ).

$X^{2}$ (or Fisher's exact test when appropriate) significant $\mathrm{p}$-values and $\mathrm{OR}(95 \% \mathrm{Cl})$, using the Madeira reference set as a control, are shown in bold (dominant model). * Heterozygote model, significant p-values and OR $(95 \% \mathrm{Cl})$ for comparison between mild persistent and moderate-severe persistent; Dominant model, Fisher's exact test $\mathrm{p}$-value $=0.038, \mathrm{OR}(95 \% \mathrm{Cl}) 4.667(0.953-22.851)$; ** Recessive model, significant $\mathrm{p}$-values and $\mathrm{OR}(95 \% \mathrm{Cl})$ for comparison between mild persistent and moderate-severe persistent; Heterozygote model: Fisher's exact test p-value $=0.039$, OR 2.625 (1.011-6.817)

Table 4 Mean FEV 1 and FVC indexes across SNP genotypes

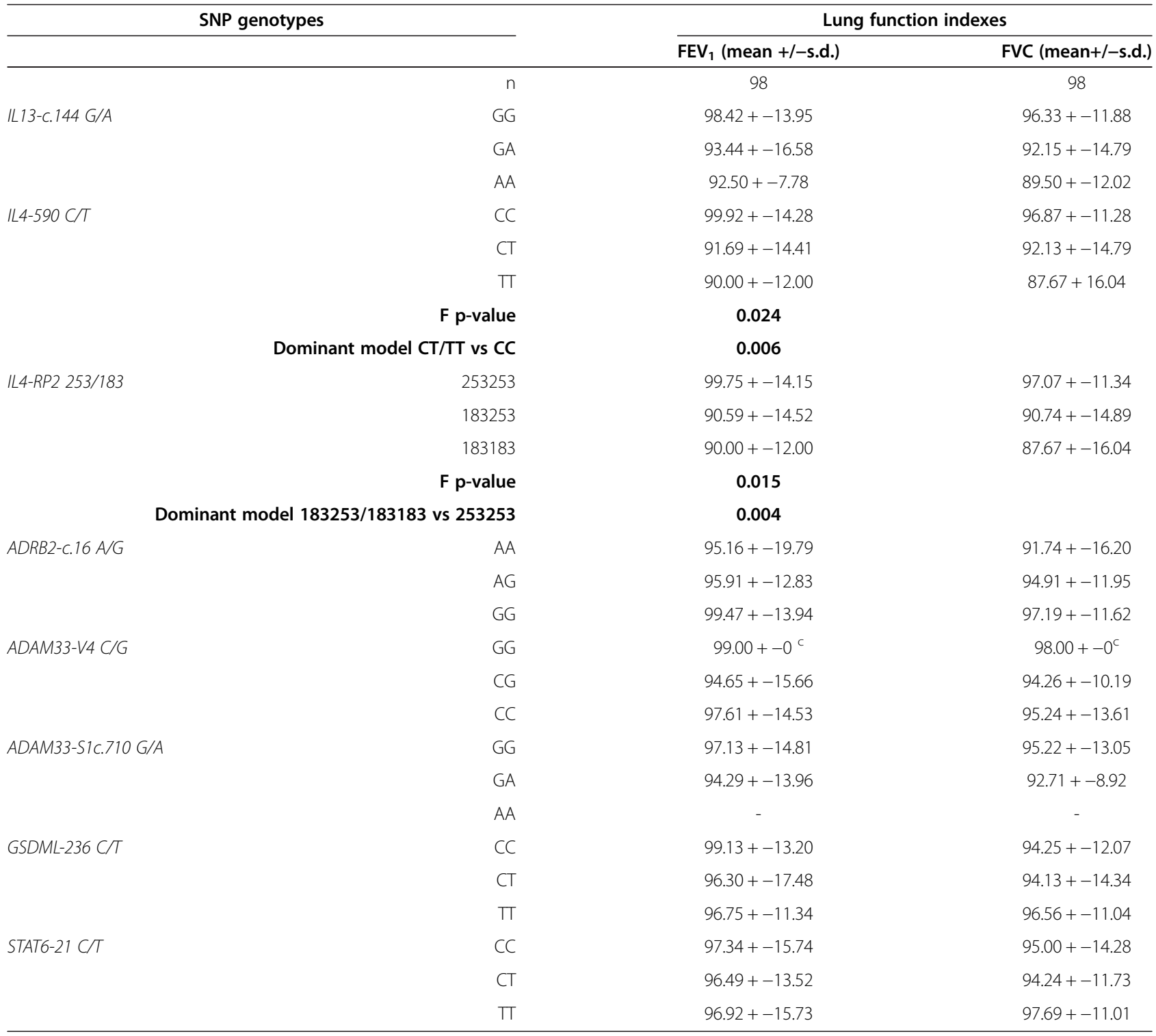

${ }^{\mathrm{c}} \mathrm{n}=1$.

A Shapiro-Wilkoxon test showed that $\mathrm{FEV}_{1}$ is normally distributed $(p>0.05)$ while FVC is not $(p=0.008)$. Thus, ANOVA was used for FEV 1 analysis while a Kruskal-Wallis test was used for FVC. 
Table 5 Skin prick tests positivity across SNP genotypes

\begin{tabular}{|c|c|c|c|c|c|c|c|}
\hline \multirow[t]{2}{*}{ Allergen panel } & & \multirow[b]{2}{*}{$\mathbf{n}$} & \multicolumn{3}{|c|}{$\begin{array}{l}\text { SNP genotypes } \\
A D A M 33-V 4 C / G\end{array}$} & \multirow[b]{2}{*}{ p-value } & \multirow[b]{2}{*}{ OR (95\% Cl) } \\
\hline & & & GG & CG & $\mathrm{CC}$ & & \\
\hline \multirow[t]{4}{*}{ Dermatophagoides pteronyssinus } & $(-)$ & 23 & 0.043 & 0.348 & 0.609 & & \\
\hline & $(+)$ & 74 & 0 & 0.203 & 0.797 & & \\
\hline & $<10 \mathrm{~mm}$ & 44 & 0 & 0.295 & 0.705 & & \\
\hline & $\geq 10 \mathrm{~mm}$ & 30 & 0 & 0.067 & 0.933 & 0.016 & $1.325(1.070-1.641)$ \\
\hline \multirow[t]{6}{*}{ Blomia tropicalis } & $(-)$ & 43 & 0.023 & 0.279 & 0.698 & & \\
\hline & $(+)$ & 54 & 0 & 0.204 & 0.796 & & \\
\hline & $<10 \mathrm{~mm}$ & 42 & 0 & 0.262 & 0.738 & & \\
\hline & $\geq 10 \mathrm{~mm}$ & 12 & 0 & 0 & 1.00 & 0.047 & $1.355(1.131-1.622)$ \\
\hline & & & \multicolumn{3}{|c|}{ STAT6-21 C/T } & & \\
\hline & & & $\mathrm{CC}$ & $\mathrm{CT}$ & $\pi$ & & \\
\hline \multirow[t]{4}{*}{ Storage mites } & $(-)$ & 53 & 0.396 & 0.472 & 0.132 & & \\
\hline & $(+)$ & 44 & 0.500 & 0.364 & 0.236 & & \\
\hline & $<10 \mathrm{~mm}$ & 35 & 0.514 & 0.429 & 0.057 & & \\
\hline & $\geq 10 \mathrm{~mm}$ & 9 & 0.444 & 0.111 & 0.444 & $0.003^{*}$ & $7.778(1.682-35.962)$ \\
\hline
\end{tabular}

Only significant associations are reported, in bold.

Storage mites: Lepidoglyphus destructor, Glycifagus domesticus, Acarus siro, Euroglyphus maynei and Tyrophagus putrescentiae allergens, classified as $\geq 10$ mm if at least one test resulted in wheal diameter $\geq 10 \mathrm{~mm}$. Recessive model.

are no exception (previously reported by our research team [7]. Our findings show that $I L 4-590 * \mathrm{CT} /$ $T T$ genotypes associate to a 2.2 -fold risk for asthma (2.4-fold for overall persistent asthma and 4-fold for moderate-severe persistent asthma) while IL4-590*T allele represents a 2 -fold risk for asthma (2.2-fold for persistent asthma and 3.4-fold for moderate-severe asthma), compared to individuals harbouring other IL4-590 C/T genotypes or allele. Our findings also indicate that IL4-RP2*253183/183183 genotypes translate into a 2-fold increased risk for asthma (2.3-fold and 2.9-fold respectively for persistent and moderate-severe persistent asthma), in

Table 6 SNP haplotype frequencies in the Madeira reference set and the asthmatics study population

\begin{tabular}{|c|c|c|c|c|c|c|c|}
\hline \multirow[t]{2}{*}{ Haplotype block } & & \multicolumn{6}{|c|}{ Study sample set } \\
\hline & & $\begin{array}{c}\text { Madeira } \\
\text { reference set }\end{array}$ & $\begin{array}{l}\text { Overall } \\
\text { asthma }\end{array}$ & $\begin{array}{l}\text { Intermittent } \\
\text { asthma }\end{array}$ & $\begin{array}{l}\text { Persistent } \\
\text { asthma }\end{array}$ & Mild & Moderate-severe \\
\hline & & $105^{a}$ & 98 & 24 & 74 & 44 & 30 \\
\hline \multirow[t]{2}{*}{ IL4-590/ IL4-RP2 } & $\mathrm{T} 183$ & 0.088 & $0.168(0.019)$ & 0.125 & $0.182(0.011)$ & 0.125 & $0.267\left(3 \times 10^{-4} / 0.029^{*}\right)$ \\
\hline & C253 & 0.894 & 0.806 & 0.833 & 0.797 & 0.852 & $0.717\left(0.004 / 0.044^{*}\right)$ \\
\hline \multirow[t]{2}{*}{ IL4-590 /ADRB2-C.16 } & $\mathrm{TA}$ & 0.018 & $0.058(0.037)$ & 0.064 & $0.055(0.048)$ & 0.031 & $0.085(0.009)$ \\
\hline & $\mathrm{TG}$ & 0.092 & 0.136 & 0.102 & 0.148 & 0.117 & $0.199(0.023)$ \\
\hline \multirow[t]{2}{*}{ IL4-RP2/ADRB2-C.16 } & $183 \mathrm{~A}$ & 0.025 & 0.057 & 0.059 & 0.056 & 0.032 & $0.089(0.026)$ \\
\hline & $183 G$ & 0.084 & 0.111 & 0.066 & 0.127 & 0.093 & $0.178(0.037)$ \\
\hline \multirow[t]{2}{*}{ IL13-c.144/IL4-590 } & GT & 0.064 & $0.134(0.018)$ & 0.098 & $0.146(0.010)$ & 0.128 & $0.166(0.010)$ \\
\hline & AT & 0.046 & 0.060 & 0.068 & 0.057 & 0.020 & $0.110\left(0.020^{*}\right)$ \\
\hline \multirow[t]{2}{*}{ IL13-C.144/IL4-RP2 } & G183 & 0.059 & 0.106 & 0.052 & $0.124(0.033)$ & 0.105 & $0.147(0.022)$ \\
\hline & A183 & 0.050 & 0.063 & 0.073 & 0.059 & 0.021 & $0.114\left(0.017^{*}\right)$ \\
\hline \multirow[t]{2}{*}{ IL13-c.144/IL4-590/IL4-RP2 } & GT183 & 0.051 & $0.107(0.041)$ & 0.054 & $0.125(0.016)$ & 0.105 & $0.148(0.009)$ \\
\hline & AT183 & 0.040 & 0.062 & 0.071 & 0.058 & 0.020 & $0.119\left(0.024 / 0.018^{*}\right)$ \\
\hline \multirow[t]{2}{*}{ IL4-590/IL4-RP2/ ADRB2-C.16 } & T183A & 0.016 & $0.055(0.038)$ & 0.052 & $0.053(0.045)$ & 0.030 & $0.082(0.008)$ \\
\hline & T183G & 0.073 & 0.113 & 0.067 & 0.129 & 0.095 & $0.184(0.013)$ \\
\hline
\end{tabular}


Table 7 TDT analysis in family trios for SNP association with asthma

\begin{tabular}{|c|c|c|c|c|}
\hline SNP allele & Valid trios (n) & TDT-test value & TDT $p$-value & OR $(95 \% \mathrm{Cl})$ \\
\hline \multicolumn{5}{|c|}{ Overall asthma } \\
\hline ADAM33-V4 ${ }^{*} C$ & 41 & 3.429 & 0.044 & $1.800(0.956-3.384)$ \\
\hline \multicolumn{5}{|c|}{ Persistent asthma } \\
\hline ADAM33-V4* ${ }^{*}$ & 30 & 5.452 & 0.015 & $2.444(1.126-5.309)$ \\
\hline \multicolumn{5}{|l|}{ Mild asthma } \\
\hline ADAM33-V4* ${ }^{*} \mathrm{C}$ & 19 & 7.200 & 0.006 & $4.000(1.337-11.965)$ \\
\hline \multicolumn{5}{|c|}{ Moderate-severe asthma } \\
\hline IL4-590*T & 19 & 3.857 & 0.039 & $2.500(0.970-6.443)$ \\
\hline IL4-RP2*183 & 17 & 5.556 & 0.015 & $3.500(1.152-10.633)$ \\
\hline
\end{tabular}

Only significant associations are reported, in bold.

particular IL4-RP2*183 allele (3.1-fold risk for moderatesevere persistent asthma). This SNP has been implicated in childhood asthma in a Chinese population, where authors suggest a link between the allele and higher expression of IL4 in asthma [24]. The findings for IL4 SNPs are further corroborated by the association of the risk genotypes to worse lung function, namely lower $\mathrm{FEV}_{1}$ index. Genotype IL4-590*TT has been previously associated with lower $\mathrm{FEV}_{1}$ index, used as a measure for asthma severity, in a population of white asthmatic subjects [51].

IL4 is a key cytokine in IgE production via Th2 pathway [52], which has been previously shown to play an important role in asthma pathogenesis [53]. Its serous levels are significantly higher in steroid-naive asthmatic children and severe forms of asthma when compared to healthy control groups $[54,55]$. From a functional perspective, it is not surprising that IL4 SNPs may regulate its transcription rates: allele $I L 4-590 * T$ allows an extra binding site for the nuclear factor of activated T-cells (NFAT) at IL4 promoter, leading to a 3-fold higher transcription rate [23]; haplotypes with IL4-RP2*183 and SNPs within IL4 promoter account for high IL4 expression [56].

The case-control associations of $I L 4-590 * T$ and IL4-RP $2 \% 183$ to moderate-severe persistent asthma are further corroborated by TDT analysis (2.5 and 3.5-fold increased risk respectively). TDT is a family-based test robust against population stratification $[57,58]$ defined as the presence of multiple subgroups with distinct allele frequencies within a population [59]. Although stratification is mostly noticed in recent history of admixture [60], we cannot disregard the considerable sub-Saharan and northern African proportion in the Madeira genetic background, due to the North Atlantic slavetrade on the $16^{\text {th }}-19^{\text {th }}$ centuries and previously confirmed by Y-chromosome [61] and mtDNA studies [62].

Previous studies have related ADRB2-c.16*GG to asthma onset and severity $[25,26]$. Conversely, our data suggest heterozygous $A D R B 2-c .16^{*} A G$ as 3.5-fold risk genotype for moderate-severe asthma. In the absence of functional studies, we can only hypothesize that heterodimeric ADRB2 receptors on the bronchial smooth muscle may be less stable or bind to a more restricted scope of products than homodimeric receptors, therefore enhancing more severe forms of asthma. However, the high heterozygosity for $A D R B 2-c .16$ is found not only in patient's subgroups but also in the Madeira reference set and other population sets [63-65]. Even though it deserves more attention, this may indicate heterozygote advantage for this SNP or other in linkage disequilibrium, in a metabolic pathway that may or may not relate to asthma pathogenesis. Other examples of heterozygote advantage in $A D R B 2$ exist, such as $A D R B 2-c .27 * C G$ that is protective against lung function decline [66] and accounts for a decreased risk of asthma [67].

In our data, GSDML-236*TT genotype is found to be a protective for asthma severity, with a 4-fold significantly lower frequency in moderate-severe asthma, as opposed to mild. GSDML-236C/T polymorphism has been related to asthma predisposition, severity and/or asthma-related phenotypes in a number of studies [31-39]. However, our results are in contrast to certain previous studies, which suggest this genotype is a genetic risk factor for the disease severity $[32,35,37,38]$. The GSDML encodes for gasdermin $B$ protein expressed in epithelial barrier function and skin differentiation, influencing the expression of the neighbouring gene $O R M D L 3$ and thus contributing to asthma susceptibility [34].

The case-control association in our dataset does not support the influence of $A D A M 33-V 4 C / G$ or $A D A M 33-$ $S 1 c .710 G / A$ in asthma, contrary to some previous work [27-30] and consistent with other studies [68]. ADAM33$V 4 * C$ allele was nevertheless marginally over transmitted to Madeira asthmatics, as suggested by TDT analysis (1.8-fold risk for overall asthma, 2.4-fold risk for persistent asthma and 4-fold risk for mild asthma). A similar trend of association was seen in Caucasian children with asthma and bronchial responsiveness ( $\mathrm{p}$-value $=0.0959)$ [27]. Located at 3'-UTR, ADAM33-V4C/G SNP may 
influence the expression of its encoded desintegrin and metallopeptidase domain 33 in airway smooth muscle and lung fibroblasts $[27,69,70]$ thus playing a role on airway remodeling and bronchial responsiveness [27,71]. In addition, our study associates $A D A M 33-V 4 * C C$ to a wheal size $\geq 10 \mathrm{~mm}$ both in Dermatophagoides pteronyssinus and Blomia tropicalis, in accordance with a previous study relating $A D A M 33-V 4 * C C$ to high levels of IgE against Blomia tropicalis ( $\mathrm{Z}$ score: 2.089, $\mathrm{p}=0.03$ ) [72].

No significant association with the disease risk was detected for STAT6-21C/T, similar to the analysis in [73] but contrary to other studies [19,40-44]. However, STAT6-21*TT is overrepresented in asthmatics with a $\geq 10 \mathrm{~mm}$ wheal size reaction to storage mites and shows a significant epistatic interaction with $I L 4-590 \mathrm{C} / T$ between moderate-severe persistent and intermittent asthma. The enhanced allergic response is not unexpected since STAT6 is a signal transducer and activator of transcription enrolled in the regulation of $\mathrm{IgE}$ expression $[40,52,74]$ whose STAT6-21*T allele promotes higher levels of IgE [19].

Finally, the haplotype analysis was significant for SNPs at 5q31, namely IL4-590*T and IL4-RP2*183 in overall asthma, persistent asthma and moderate-severe persistent asthma. Haplotypes of IL4-RP2*183 and SNPs within the promoter of IL4 have been found to account for high IL4 expression [56]. Our results also indicate the synergistic effect of $I L 13 c .144 * G$ and $A D R B 2 * G$ with either IL4-590*T or IL4-RP2*183 or both for the onset of asthma persistent phenotypes. Nevertheless, their combination equals or slightly lowers the statistical significance of IL4-590/ IL4-RP2*T183 haplotype in the same classes.

\section{Conclusion}

In conclusion, this study has replicated previously reported genetic associations and brought light to new associations of polymorphisms, individually or in haplotype, to asthma susceptibility, persistence and/or severity in the Madeira island population. IL4-590C/T and IL4-RP2253/183 seem to play an important role in the development of the disease, especially its moderate-severe persistent forms, as demonstrated by allele and haplotype case-control tests, TDT analysis, and significantly poorer $\mathrm{FEV}_{1}$ index. $G S D M L * C T / T T$ and $A D R B 2 c .16 * A G$ are found to predict asthma severity in case-control association, respectively as risk and protective factors for moderate-severe forms. ADAM33-V4*C and STAT-21*TT seem to enhance the allergic response to Dermatophagoides pteronyssinus and Blomia tropicalis and to storages mites, respectively, and the first is further highlighted by TDT analysis as a risk factor for mild persistent asthma. The combined genotyping of IL4-590C/T, IL4-RP2-253/183, GSDML-236C/T and $A D A M 33-V 4 C / G$ could be of clinical relevance in ascertaining the risk of asthma onset and/or its persistence and severity, thus helping to define appropriate strategies for asthma healthcare in this island.

\section{Methods}

\section{Participants}

A sample of 98 atopic asthmatics, aged between 6 and 25 years old, and their parents (fathers $\mathrm{n}=88$ and mothers $\mathrm{n}=96$ ) were recruited at the Immunoalergology Unit, Dr. Nélio Mendonça Hospital, in Funchal, Madeira. For all participants, the last three generations of ancestors were born and lived in Madeira island. The diagnosis of asthma was based on clinical criteria associated with lung function and the SPT. For the epidemiologic characterization we deployed the ISAAC questionnaire to the asthmatic population and their parents. Following the GINA guidelines [75], pattern and frequency of symptoms associated with lung function were used to classify asthma into intermittent $(\mathrm{n}=24)$ and persistent $(\mathrm{n}=74)$, and the severity in persistent asthma was further classified as mild $(\mathrm{n}=44)$, moderate $(\mathrm{n}=26)$ and severe $(\mathrm{n}=4)$. Given the small number of patients, the moderate and severe subgroups were merged. Asthma induced by exercise and associated to aspirin was excluded.

\section{Ethics statement}

The study had the approval of the Ethics Committee of Dr. Nélio Mendonça Hospital and the informed consent of the participants.

\section{Allergy profile}

The SPT was tested for an optimized battery with the most common aeroallergens in this island: house dust mite (Dermatophagoides pteronyssinus, Blomia tropicalis); storage mite (Lepidoglyphus destructor, Glycyphagus domesticus, Acarus siro, Euroglyphus maynei, Tyrophagus putrescentiae); Mix fungi (Fungus I, Fungus II); indoor fungi (Aspergillus fumigatus, Mucor sp.) and cat and dog. STP results were interpreted according to mean wheal size: positive $\geq 3 \mathrm{~mm}$, sensitization degree $\leq 10 \mathrm{~mm}$ or $\geq 10 \mathrm{~mm}$.

\section{DNA extraction and genotyping}

Patients' blood samples were collected by venipuncture in $8 \mathrm{ml}$ EDTA blood collection tubes and their DNA was extracted by salting-out method (adapted from [76]). Their parents contributed with saliva samples, collected in Oragene•DNA (OG-250) kits (Oragene). The DNA extraction followed the manufacturer's instructions.

A sample of 110 unrelated individuals, whose ancestry was of local origin for the last three generations, was obtained from the Blood Sample Bank of Human Genetics Laboratory (LGH) and their DNA extraction was performed by a standard phenol-chloroform protocol (adapted from [77]). These constitute the Madeira population reference sample set, although their disease status is 
unknown. The reference sample set was not matched to the patient's group to uphold a less biased study design. Each SNP (Table 1) was analysed by TaqMan real-time PCR (Applied Biosystems) according to the manufacturer's instructions, in a 7300 System SDS Software v1.4.

\section{Statistical analysis}

The statistical analysis was performed using SPSS (IBM SPSS Statistics, version 19.0.0), except for the Hardy-Weinberg Equilibrium (HWE) for each polymorphism, determined in ARLEQUIN version 3.11 [78]. Gender and SPT data among subgroups of asthma persistence and severity were analysed using Fisher's exact test, to account for the small sample size.

Following a Shapiro-Wilkoxon test of normality, the association analysis of $\mathrm{FEV}_{1}$ to asthma persistence and severity was performed using a t-test (normal distribution), while a Mann-Whitney test was used for FVC (due to its non-normal distribution). The analysis of $\mathrm{FEV}_{1}$ and FVC indexes among SNP genotypes was tested using ANOVA (with Bonferroni post-hoc correction) and Kruskal-Wallis test, respectively.

The association of SNP genotypes and alleles to asthma susceptibility and severity, for multiple genetic models, were assessed by $x^{2}$ (or Fisher's exact tests where appropriate) and corresponding odds ratio (OR) determined with a 95\% CI. Haplotypes were generated with Haploview version 4.2 [79] and their association with the disease was analysed with the hap-assoc option in PLINK [80]. Epistatic interactions between pairs of SNPs were assessed with the PLINK option -epistasis -epi1 1. Permutation procedures were used to obtain significance levels empirically and results were interpreted at a significance level set for $\mathrm{p}<0.05$.

The transmission disequilibrium test (TDT) was determined through a McNemar test [81], based on data from heterozygous parents and the frequency of allelic transmission to affected offspring. The corresponding p-value (considered at a 0.05 significance level) and OR (95\% CI) were determined.

To reduce the likelihood of commiting a Type I error due to multiple testing, the Benjamini \& Hochberg procedure [82] was adopted for each set of results (presented in distinct tables) to control the false discovery rate set at $\mathrm{Q}=0.20$.

\section{Additional files}

Additional file 1: Skin prick tests positivity across asthma persistence and severity subgroups. The table describes the qualitative (positive vs. negative) and quantitative $(<10 \mathrm{~mm}$ vs. $\geq 10 \mathrm{~mm})$ reaction to common allergens in Madeira island (Dermatophagoides pteronyssinus, Blomia tropicalis, Storage mites, Mix fungi, Indoor fungi, cat and dog) across overall asthma and asthma severity categories (intermittent, persistent, mild and moderate-severe).
Additional file 2: SNP allelic frequencies for the Madeira reference set and asthmatics study population. The table describes the allelic frequencies for SNPS IL4-590, IL4-RP2, IL13-C.144, ADRB2-C.16, ADAM33-V4, ADAM33-S1C.710, GSDML-236, STAT6-21) across the reference group, overall asthma and asthma severity categories (intermittent, persistent, mild and moderate-severe).

\section{Abbreviations}

ADAM33: A Disintegrin and Metalloprotease 33; ADRB2: Beta-2-adrenergic receptor; $\mathrm{FEV}_{1}$ : Forced Expiratory Volume in 1 second; FVC: Forced Vital Capacity; GINA: Global Initiative for Asthma; GSDML: Gasdermin-like; IL4: Interleukin 4; IL13: Interleukin 13; SNPs: Single Nucleotide Polymorphisms; SPT: Skin Prick Tests; STAT6: Signal Transducer and Activator of Transcription 6 (STAT6); TDT: Transmission Disequilibrium Test.

\section{Competing interests}

The authors declare that they have no competing interests.

\section{Authors' contributions}

RC and ATF conceived and designed the study, AGB and ATF performed the DNA extraction and genotyping, RC, SO, PO, DR and TS, characterized epidemiologically the parents and collected biological products, MR designed the database, AGB and AR analyzed the data, AGB, AR and RC wrote the manuscript. All authors read and approved the final manuscript.

\section{Acknowledgements}

This project had the financial support of FEDER within the framework of the INTERREGIII C program. Anabela Berenguer is a recipient of a PhD scholarship from Fundação para a Ciência e Tecnologia (FCT) with the reference SFRH/BD/31273/2006. Ph.D. Ana Teresa Fernandes passed away during the course of the project.

\section{Author details}

'Human Genetics Laboratory, University of Madeira, 9000-390 Funchal, Portugal. ${ }^{2}$ Immunoalergology Unit, Dr. Nélio Mendonça Hospital, SESARAM, E.P.E, Funchal, Portugal. ${ }^{3}$ Unit of Statistics, Dr. Nélio Mendonça Hospital, SESARAM, E.P.E, Funchal, Portugal. ${ }^{4}$ Medical Sciences Unit, Center of Life Sciences, University of Madeira, 9000-390 Funchal, Portugal. ${ }^{5}$ Department of Computer Science and Engineering, University of Oulu, PL 4500, 90014 Oulu, Finland.

Received: 19 March 2014 Accepted: 27 August 2014

Published: 4 September 2014

\section{References}

1. Reddel HK, Taylor DR, Bateman ED, Boulet LP, Boushey HA, Busse WW Casale TB, Chanez P, Enright PL, Gibson PG, de Jongste JC, Kerstjens HA, Lazarus SC, Levy ML, O'Byrne PM, Partridge MR, Pavord ID, Sears MR, Sterk PJ, Stoloff SW, Sullivan SD, Szefler SJ, Thomas MD, Wenzel SE, American Thoracic Society/European Respiratory Society Task Force on Asthma Control and Exacerbations: An official american thoracic society/european respiratory society statement: asthma control and exacerbations. Am J Respir Crit Care Med 2009, 180(Suppl1):59-99.

2. Cookson WOC: Asthma genetics. Chest 2002, 121(Suppl 3):7-13.

3. Su MW, Tung KY, Liang PH, Tsai CH, Kuo NW, Lee YL: Gene-gene and gene-environmental interactions of childhood asthma: a multifactor dimension reduction approach. PLoS One 2012, 7(Suppl 2):e30694.

4. Samolinski B, Fronczak A, Kuna P, Akdis CA, Anto JM, Bialoszewski AZ, Burney PG, Bush A, Czupryniak A, Dahl R, Flood B, Galea G, Jutel M, Kowalski ML, Palkonen S, Papadopoulos N, Raciborski F, Sienkiewicz D, Tomaszewska A, Von Mutius E, Willman D, Włodarczyk A, Yusuf O, Zuberbier T, Bousquet J, Niggemann B: Prevention and control of childhood asthma and allergy in the EU from the public health point of view: an urgent need to fill the gaps. Allergy 2012, 67(Suppl 6):726-731.

5. To T, Stanojevic S, Moores G, Gershon AS, Bateman ED, Cruz AA, Boulet LP: Global asthma prevalence in adults: findings from the cross-sectional world health survey. BMC Public Health 2012, 12:204.

6. Pinto JR, Almeida MM: Epidemiology of asthma in schoolchildren in Portuguese speaking regions. Rev Fr Allergol 2005, 45:547-549. 
7. Berenguer AG, Câmara RA, Brehm AD, Oliveira S, Fernandes AT: Distribution of polymorphisms IL4-590 C/T and IL4-RP2 in the human populations of Madeira, Azores, Portugal, Cape Verde and Guinea-Bissau. Int J Mol Epidemiol Genet 2012, 3(Suppl 2):179-183.

8. von Mutius E: Gene-environment interactions in asthma. J Allergy Clin Immunol 2009, 123(Suppl 1):3-11.

9. Vercelli D: Discovering susceptibility genes for asthma and allergy. Nat Rev Immunol 2008, 8(Suppl 3):169-182.

10. Heinzmann A, Mao X-Q, Akaiwa M, Kreomer RT, Gao P-S, Ohshima K, Umeshita R, Abe Y, Braun S, Yamashita T, Roberts MH, Sugimoto R, Arima K, Arinobu Y, Yu B, Kruse S, Enomoto T, Dake Y, Kawai M, Shimazu S, Sasaki S, Adra CN, Kitaichi M, Inoue H, Yamauchi K, Tomichi N, Kurimoto F, Hamasaki N, Hopkin JM, Izuhara K, et al: Genetic variants of IL-13 signalling and human asthma and atopy. Hum Mol Genet 2000, 9(Suppl 4):549-559.

11. Chen W, Ericksen MB, Levin LS, Hershey GK: Functional effect of the R110Q IL13 genetic variant alone and in combination with IL4RA genetic variants. J Allergy Clin Immunol 2004, 114(Suppl 3):553-560.

12. Vladich FD, Brazille SM, Stern D, Peck ML, Ghittoni R, Vercelli D: IL-13 $\mathrm{R} 130 \mathrm{Q}$, a common variant associated with allergy and asthma, enhances effector mechanisms essential for human allergic inflammation. $J$ Clin Invest 2005, 115(Suppl 3):747-754.

13. Bottema RW, Nolte IM, Howard TD, Koppelman GH, Dubois AE, de Meer G, Kerkhof M, Bleecker ER, Meyers DA, Postma DS: Interleukin 13 and Interleukin 4 Receptor-alpha Polymorphisms in Rhinitis and Asthma. Int Arch Allergy Immunol 2010, 153(Suppl 3):259-267.

14. Brightling CE, Saha S, Hollins F: Interleukin-13: prospects for new treatments. Clin Exp Allergy 2010, 40(Suppl 1):42-49.

15. Chu Y, Hua L, Liu Q, Bao Y: A common variant associated with asthma, interleukin $13 \mathrm{R} 130 \mathrm{Q}$, promotes the production of IgE. Int J Immunogenet 2012, 39(Suppl 4):308-313.

16. Cui L, Jia J, Ma C-F, Li S-Y, Wang Y-P, Guo X-M, Li Q, Yu H-B, Liu W-H, Gao LB: IL-13 polymorphisms contribute to the risk of asthma: a meta-analysis. Clin Biochem 2012, 45(Suppl 4-5):285-288.

17. Wang W, Halmurat W, Yilihamu S, Xiang YB, Ablikemu A: A study on the relationship between interleukin-4 promoter polymorphism and asthma in a Xinjiang Uyger population. Zhonghua Jie He He Hu Xi Za Zhi 2004 27(Suppl 7):460-464.

18. Gervaziev YV, Kaznacheev VA, Gervazieva VB: Allelic polymorphisms in the interleukin-4 promoter regions and their association with bronchial asthma among the Russian population. Int Arch Allergy Immunol 2006, 141(Suppl 3):257-264.

19. Kabesch M, Schedel M, Carr D, Woitsch B, Fritzsch C, Weiland SK, von Mutius E: IL-4/IL-13 pathway genetics strongly influence serum lgE levels and childhood asthma. J Allergy Clin Immunol 2006, 117(Suppl 2):269-274.

20. Chiang $\mathrm{CH}$, Tang YC, Lin MW, Chung MY: Association between the IL-4 promoter polymorphisms and asthma or severity of hyperresponsiveness in Taiwanese. Respirology 2007, 12(Suppl 1):42-48.

21. de Guia RM, Ramos JD: The -590C/T IL4 single-nucleotide polymorphism as a genetic factor of atopic allergy. Int J Mol Epidemiol Genet 2010, 1 (Suppl 1):67-73.

22. Li Y, Guo B, Zhang L, Han J, Wu B, Xiong H: Association between C-589T polymorphisms of interleukin-4 gene promoter and asthma: a metaanalysis. Respir Med 2008, 102(Suppl 7):984-992.

23. Rockman MV, Hahn MW, Soranzo N, Goldstein DB, Wray GA: Positive selection on a human-specific transcription factor binding site regulating IL4 expression. Curr Biol 2003, 13(Suppl 23):2118-2123.

24. Fang GF, Fan $X Y$, Shen FH: The relationship between polymorphisms of interleukin4 gene and silicosis. Biomed Environ Sci 2011, 24(Suppl 6):678-682.

25. Sato R: The role of beta 2-adrenoceptor gene polymorphisms in asthma. Hokkaido lgaku Zasshi 2000, 75(Suppl 2):81-94

26. Contopoulos-Ioannidis DG, Manoli EN, loannidis JPA: Meta-analysis of the association of b2- adrenergic receptor polymorphisms with asthma phenotypes. J Allergy Clin Immunol 2005, 115(Suppl 5):963-972.

27. Eerdewegh PV, Little RD, Dupuis J, Del Mastro RG, Falls K, Simon J, Torrey D, Pandit S, McKenny J, Braunschweiger K, Walsh A, Liu Z, Hayward B, Folz C, Manning SP, Bawa A, Saracino L, Thackston M, Benchekroun Y, Capparell N, Wang $M$, Adair R, Feng $Y$, Dubois J, FitzGerald MG, Huang H, Gibson R, Allen KM, Pedan A, Danzig MR, et al: Association of the ADAM33 gene with asthma and bronchial hyperresponsiveness. Nature 2002, 418(Suppl 6896):426-430
28. Howard TD, Postma DS, Jongepier H, Moore WC, Koppelman GH, Zheng SL, $\mathrm{Xu}$ J, Bleecker ER, Meyers DA: Association of a disintegrin and metalloprotease 33 (ADAM33) gene with asthma in ethnically diverse populations. J Allergy Clin Immunol 2003, 112(Suppl 4):717-722.

29. Su D, Zhang $X$, Sui H, Lü F, Jin L, Zhang J: Association of ADAM33 gene polymorphisms with adult allergic asthma and rhinitis in a Chinese Han population. BMC Med Genet 2008, 9:82.

30. Qu S, Sun D, Wang $Y$, Zhang $C, L V Y$, Yao L: Association of ADAM33 polymorphisms with childhood asthma in a northern Chinese population. Exp Mol Pathol 2011, 91(Suppl 3):775-779.

31. Moffatt MF, Kabesch M, Liang L, Dixon AL, Strachan D, Heath S, Depner M, von Berg A, Bufe A, Rietschel E, Heinzmann A, Simma B, Frischer T, WillisOwen SA, Wong KC, Illig T, Vogelberg C, Weiland SK, von Mutius E, Abecasis GR, Farrall M, Gut IG, Lathrop GM, Cookson WO: Genetic variants regulating ORMDL3 expression contribute to the risk of childhood asthma. Nature 2007, 448(Suppl 7152):470-473

32. Galanter J, Choudhry S, Eng C, Nazario S, Rodríguez-Santana JR, Casal J, Torres-Palacios A, Salas J, Chapela R, Watson HG, Meade K, LeNoir M, Rodríguez-Cintrón W, Avila PC, Burchard EG: ORMDL3 gene is associated with asthma in three ethnically diverse populations. Am J Respir Crit Care Med 2008, 177(Suppl 11):1194-1200.

33. Madore AM, Tremblay K, Hudson TJ, Laprise C: Replication of an association between 17q21 SNPs and asthma in a French-Canadian familial collection. Hum Genet 2008, 123(Suppl 1):93-95.

34. Tavendale R, Macgregor DF, Mukhopadhyay S, Palmer CN: A polymorphism controlling ORMDL3 expression is associated with asthma that is poorly controlled by current medications. J Allergy Clin Immunol 2008, 121(Suppl 4):860-863.

35. Bisgaard H, Bønnelykke K, Sleiman PM, Brasholt M, Chawes B, Kreiner-Møller E, Stage M, Kim C, Tavendale R, Baty F, Pipper CB, Palmer CN, Hakonarsson $\mathrm{H}$ : Chromosome $17 \mathrm{q} 21$ gene variants are associated with asthma and exacerbations but not atopy in early childhood. Am J Respir Crit Care Med 2009, 179(Suppl 3):179-185.

36. Wu H, Romieu I, Sienra-Monge JJ, Li H, del Rio-Navarro BE, London SJ: Genetic variation in ORM1-like 3 (ORMDL3) and gasdermin-like (GSDML) and childhood asthma. Allergy 2009, 64(Suppl 4):629-635.

37. Halapi E, Gudbjartsson DF, Jonsdottir GM, Bjornsdottir US, Thorleifsson G, Helgadottir H, Williams C, Koppelman GH, Heinzmann A, Boezen HM, Jonasdottir A, Blondal T, Gudjonsson SA, Jonasdottir A, Thorlacius T, Henry AP, Altmueller J, Krueger M, Shin HD, Uh ST, Cheong HS, Jonsdottir B, Ludviksson BR, Ludviksdottir D, Gislason D, Park CS, Deichmann K, Thompson PJ, Wjst M, Hall IP, et al: A sequence variant on $17 q 21$ is associated with age at onset and severity of asthma. Eur J Hum Genet 2010, 18(Suppl 8):902-908.

38. Binia A, Khorasani N, Bhavsar PK, Adcock I, Brightling CE, Chung KF, Cookson WO, Moffatt MF: Chromosome 17q21 SNP and severe asthma. J Hum Genet 2011, 56(Suppl 1):97-98.

39. Yu J, Kang MJ, Kim BJ, Kwon JW, Song YH, Choi WA, Shin YJ, Hong SJ: Polymorphisms in GSDMA and GSDMB are associated with asthma susceptibility. Atopy and BHR. Pediatr Pulmonol 2011, 46(Suppl 7):701-708.

40. Schedel M, Carr D, Klopp N, Woitsch B, Illig T, Stachel D, Schmid I, Fritzsch C, Weiland SK, von Mutius E, Kabesch M: A signal transducer and activator of transcription 6 haplotype influences the regulation of serum lgE levels. J Allergy Clin Immunol 2004, 114(Suppl 5):1100-1105.

41. Weidinger S, Klopp N, Wagenpfeil S, Rümmler L, Schedel M, Kabesch M, Schäfer T, Darsow U, Jakob T, Behrendt H, Wichmann HE, Ring J, Illig T: Association of a STAT 6 haplotype with elevated serum IgE levels in a population based cohort of white adults. J Med Genet 2004, 41(Suppl 9):658-663.

42. Daley D, Lemire M, Akhabir L, Chan-Yeung M, He JQ, McDonald T, Sandford A, Stefanowicz D, Tripp B, Zamar D, Bosse Y, Ferretti V, Montpetit A, Tessier MC, Becker A, Kozyrskyj AL, Beilby J, McCaskie PA, Musk B, Warrington N, James A, Laprise C, Palmer LJ, Paré PD, Hudson TJ: Analyses of associations with asthma in four asthma population samples from Canada and Australia. Hum Genet 2009, 125(Suppl 4):445-459.

43. Schedel M, Frei R, Bieli C, Cameron L, Adamski J, Lauener R, Kabesch M: An IgE-associated polymorphism in STAT6 alters NF-kB binding, STAT6 promoter activity, and mRNA expression. J Allergy Clin Immunol 2009, 124(Suppl 3):583-589.

44. Kavalar MS, Balantic M, Silar M, Kosnik M, Korosec P, Rijavec M: Association of ORMDL3, STAT6 and TBXA2R gene polymorphisms with asthma. Int Immunogenet 2012, 39(Suppl 1):20-25. 
45. Cantagrel A, Navaux F, Loubet-Lescoulié P, Nourhashemi F, Enault G, Abbal M Constantin A, Laroche M, Mazières B: Interleukin-1beta, interleukin-1 receptor antagonist, interleukin-4, and interleukin-10 gene polymorphisms: relationship to occurrence and severity of rheumatoid arthritis. Arthritis Rheum 1999, 42(Suppl 6):1093-1100.

46. The International HapMap Consortium: The International HapMap Project. Nature 2003, 426:789-796.

47. Lunetta KL: Statistical primer for cardiovascular research. Circulation 2008 118:96-101

48. Ramsey CD, Celedón JC, Sredl DL, Weiss ST, Cloutier MM: Predictors of disease severity in children with asthma in Hartford. Connecticut Pediatr Pulmonol 2005, 39(Suppl 3):268-275.

49. Kim TB, Park CS, Bae YJ, Cho YS, Moon HB, COREA Study Group: Factors associated with severity and exacerbation of asthma: a baseline analysis of the cohort for reality and evolution of adult asthma in Korea (COREA). Ann Allergy Asthma Immunol 2009, 103(Suppl 4):311-317.

50. Forno E, Celedón JC: Predicting asthma exacerbations in children. Curr Opin Pulm Med 2012, 18(Suppl 1):63-69.

51. Burchard EG, Silverman EK, Rosenwasser LJ, Borish L, Yandava C, Pillari A, Weiss ST, Hasday J, Lilly CM, Ford JG, Drazen JM: Association between a sequence variant in the IL-4 gene promoter and $\mathrm{FEV}_{1}$ in asthma. Am J Respir Crit Care Med 1999, 160:919-922.

52. Oh CK, Geba GP, Molfino N: Investigational therapeutics targeting the IL-4/IL-13/STAT-6 pathway for the treatment of asthma. Eur Respir Rev 2010, 19(Suppl 115):46-54.

53. Grünig G, Corry DB, Reibman J, Wills-Karp M: Interleukin 13 and the evolution of asthma therapy. Am J Clin Exp Immunol 2012, 1(Suppl 1):20-27.

54. Abdulamir AS, Hafidh RR, Abubakar F: Different inflammatory mechanisms in lungs of severe and mild asthma: crosstalk of NF-kappa-B, TGFbeta1, Bax, Bcl-2, IL-4 and IgE. Scand J Clin Lab Invest 2009, 69(Suppl 4):487-495

55. Lama M, Chatterjee M, Nayak CR, Chaudhuri TK: Increased interleukin-4 and decreased interferon- $\gamma$ levels in serum of children with asthma. Cytokine 2011, 55(Suppl 3):335-338.

56. Nakashima H, Miyake K, Inoue Y, Shimizu S, Akahoshi M, Tanaka Y, Otsuka T, Harada M: Association between IL-4 genotype and IL-4 production in the Japanese population. Genes Immun 2002, 3(Suppl 2):107-109.

57. Sebro R, Rogus JJ: The power of the Transmission Disequilibrium Test in the presence of population stratification. Eur J Hum Genet 2010, 18(Suppl 9):1032-1038.

58. Lewis CM: Genetic association studies: design, analysis and interpretation. Brief Bioinform 2002, 3(Suppl 2):146-153.

59. Cardon LR, Bell Jl: Association study designs for complex diseases. Nat Rev Genet 2001, 2(Suppl 2):91-99.

60. Freedman ML, Reich D, Penney KL, McDonald GJ, Mignault AA, Patterson N, Gabriel SB, Topol EJ, Smoller JW, Pato CN, Pato MT, Petryshen TL, Kolonel LN, Lander ES, Sklar P, Henderson B, Hirschhorn JN, Altshuler D: Assessing the impact of population stratification on genetic association studies. Nat Genet 2004, 36(Suppl 4):388-393.

61. Gonçalves R, Freitas A, Branco M, Rosa A, Fernandes AT, Zhivotovsky LA, Underhill PA, Kivisild T, Brehm A: Y-chromosome Lineages from Portugal, Madeira and Açores Record Elements of Sephardim and Berber Ancestry. Ann Hum Genet 2005, 69(Suppl 4):443-454

62. Brehm A, Pereira L, Kivisild T, Amorim A: Mitochondrial portraits of the Madeira and Açores archipelagos witness different genetic pools of its settlers. Hum Genet 2003, 114(Suppl 1):77-86.

63. Binaei S, Christensen M, Murphy C, Zhang Q, Quasney M: $\beta 2$-Adrenergic receptor polymorphisms in children with status asthmaticus. Chest 2003 123(Suppl 3):375.

64. Santillan AA, Camargo CA Jr, Ramirez-Rivera A, Delgado-Enciso I, Rojas-Martinez A, Cantu-Diaz F, Barrera-Saldaña HA: Association between $\beta 2$-adrenoceptor polymorphisms and asthma diagnosis among Mexican adults. J Allergy Clin Immunol 2003, 112(Suppl 6):1095-1100.

65. Shachor J, Chana Z, Varsano S, Erlich T, Goldman E, Dror Y, Yakovy I, Navon $\mathrm{R}$ : Genetic polymorphisms of the beta-2 adrenergic receptor in Israelis with severe asthma compared to non-asthmatic Israelis. Isr Med Assoc J 2003, 5(Suppl 11):821-824.

66. Joos L, Weir TD, Connett JE, Anthonisen NR, Woods R, Paré PD, Sandford AJ: Polymorphisms in the $B 2$ adrenergic receptor and bronchodilator response, bronchial hyperresponsiveness, and rate of decline in lung function in smokers. Thorax 2003, 58(Suppl 8):703-707.
67. Thakkinstian A, McEvoy M, Minelli C, Gibson P, Hancox B, Duffy D, Thompson J, Hall I, Kaufman J, Leung TF, Helms PJ, Hakonarson H, Halpi E, Navon R, Attia J: Systematic review and meta-analysis of the association between b2-Adrenoceptor polymorphisms and asthma: a huge review. Am J Epidemiol 2005, 162(Suppl 3):201-211.

68. Song GG, Kim JH, Lee YH: Association between ADAM33 S2 and ST+4 polymorphisms and susceptibility to asthma: a meta-analysis. Gene 2013, 524(Suppl 1):72-78.

69. Holloway JW, Yan IA, Holgate ST: Genetics of allergic disease. J Allergy Clin Immunol 2010, 125(Suppl 2):81-94.

70. Schedel M, Depner M, Schoen C, Weiland SK, Vogelberg C, Niggemann B, Lau S, Illig T, Klopp N, Wahn U, von Mutius E, Nickel R, Kabesch M: The role of polymorphisms in ADAM33, a disintegrin and metalloprotease 33, in childhood asthma and lung function in two German populations. Respir Res 2006, 7:91.

71. Yang Y, Wicks J, Haitchi HM, Powell RM, Manuyakorn W, Howarth PH, Holgate ST, Davies DE: Regulation of A disintegrin and Metalloprotease-33 expression by transforming growth factor-beta. Am J Respir Cell Mol Biol 2012, 46(Suppl 5):633-640.

72. Vergara Cl, Acevedo N, Jiménez S, Martínez B, Mercado D, Gusmão L, Barnes KC, Caraballo L: A Six-SNP haplotype of ADAM33 is associated with asthma in a population of Cartagena, Colombia. Int Arch Allergy Immunol 2010, 152(Suppl 1):32-40

73. Duetsch G, Illig T, Loesgen S, Rohde K, Klopp N, Herbon N, Gohlke H, Altmueller J, Wjst M: STAT6 as an asthma candidate gene: polymorphism- screening, association and haplotype analysis in a Caucasian sib-pair study. Hum Mol Genet 2002, 11(Suppl 6):613-621.

74. Nofziger C, Vezzoli V, Dossena S, Schönherr T, Studnicka J, Nofziger J, Vanoni S, Stephan S, Silva ME, Meyer G, Paulmichl M: STAT6 Links IL-4/IL-13 stimulation with pendrin expression in asthma and chronic obstructive pulmonary disease. Clin Pharmacol Ther 2011, 90(Suppl 3):399-405.

75. The Global Initiative for Asthma (GINA). http://www.ginasthma.org/.

76. Miller SA, Dykes DD, Polesky HF: A simple salting out procedure for extracting DNA from human nucleated cells. Nucleic Acids Res 1988, 16(Suppl 3):1215.

77. Sambrook J, Fritsch EF, Maniatis T: Molecular Cloning: A Laboratory Manual. Cold Spring Harbor, New York: Cold Spring Harbor Laboratory Press; 1989.

78. Excoffier L, Laval G, Schneider S: Arlequin ver. 3.0: an integrated software package for population genetics data analysis. Evol Bioinform Online 2005, 1:47-50.

79. Barrett JC, Fry B, Maller J, Daly MJ: Haploview: analysis and visualization of LD and haplotype maps. Bioinformatics 2005, 21(Suppl 2):263-265.

80. Purcell S, Neale B, Todd-Brown K, Thomas L, Ferreira MA, Bender D, Maller J, Sklar P, de Bakker PI, Daly MJ, Sham PC: PLINK: a tool set for whole-genome association and population-based linkage analyses. Am J Hum Genet 2007, 81(Suppl 3):559-575.

81. Lowry R: McNemar's test. http://vassarstats.net/propcorr.html.

82. Benjamini $Y$, Hochberg $Y$ : Controlling the false discovery rate: a practical and powerful approach to multiple testing. J R Stat Soc Series B 1995, 57(Suppl 1):289-300

doi:10.1186/0717-6287-47-40

Cite this article as: Berenguer et al:: Genetic polymorphisms and asthma: findings from a case-control study in the Madeira island population. Biological Research 2014 47:40.

\section{Submit your next manuscript to BioMed Central and take full advantage of:}

- Convenient online submission

- Thorough peer review

- No space constraints or color figure charges

- Immediate publication on acceptance

- Inclusion in PubMed, CAS, Scopus and Google Scholar

- Research which is freely available for redistribution 